\title{
35. ATTERBERG LIMITS OF SEDIMENTS FROM THE MOUTH OF THE GULF OF CALIFORNIA, DEEP SEA DRILLING PROJECT LEG 651
}

\author{
Mario Gutiérrez-Estrada, Universidad Nacionál Autónoma de Mexico, Instituto de Ciencias del Mar y Limnología, \\ México City, Mexico ${ }^{2}$ \\ Matthew H. Salisbury, Scripps Institution of Oceanography, La Jolla, California \\ and \\ Alberto Castro-del Rio, Universidad Nacionál Autónoma de Mexico, Instituto de Ciencias del Mar y Limnologia, \\ México City, Mexico ${ }^{2}$
}

\begin{abstract}
Atterberg limits have been determined for 32 unconsolidated sediment samples, ranging in composition from silty clay to sandy silt and recovered from four sites drilled at the mouth of the Gulf of California during DSDP Leg 65 . The liquid limit of the samples ranged from $41.5 \%$ to $157.5 \%$, and the plastic limit from $32.8 \%$ to $65.1 \%$. The plasticity index ranged from $5.9 \%$ to $102.0 \%$. In some samples, the water content was less than the liquid limit. The liquidity index averaged $76 \%$ while the flow and toughness indices averaged $35 \%$ and $2.18 \%$, respectively. On the basis of these limits, the sediments analyzed can be classified as inorganic clays of high plasticity, organic clays of moderate to high plasticity, and diatomaceous sands, silts, and silty clays of low plasticity.
\end{abstract}

\section{INTRODUCTION}

Atterberg limits provide the basis for a very simple but effective classification system for unconsolidated sediments (Keller and Bennett, 1973). These limits are basically the water contents at which a sediment changes from the semisolid to the plastic state and from the plastic to the liquid state. The main objective of this chapter is to present the Atterberg limits for the Quaternary deep-sea sediments recovered at Sites $482,483,484$, and 485 in the mouth of the Gulf of California during Deep Sea Drilling Project (DSDP) Leg 65 (Fig. 1). From previous studies it is anticipated that the data may be related to the environment of deposition and the physical mechanisms of sedimentation at the sites.

\section{METHODS}

Atterberg limits were determined for $3215-\mathrm{cm}$-long sections of core removed prior to splitting of the core on board ship. The samples were carefully packaged to insure against disturbance and moisture loss and then hand-carried to the Laboratorio de Mecánica de Suelos, Instituto de Ingenieria, Universidad Nacional Autónoma de México.

Measurements of the Atterberg liquid limit, $L L$, have been standardized since 1932 through the use of a mechanical liquid limit machine designed by Casagrande (1932). As defined by the American Society for Testing Materials (ASTM, 1958) and discussed by Richards (1962), the liquid limit is the water content at which two halves of a sediment cake will flow together for a distance of $1.25 \mathrm{~cm}$ along the bottom of a groove separating the two halves when the cup containing the cake is dropped 25 times for a distance of $1.0 \mathrm{~cm}$ at the rate of two drops per second.

The plastic limit test, $P L$, consists of measuring the lowest water content at which the sediment sample can be rolled into threads $3 \mathrm{~mm}$ in diameter without their breaking into pieces (ASTM, 1958; Richards, 1962). Following the recommendations of Casagrande (1948),

\footnotetext{
${ }^{1}$ Lewis, B. T. R., Robinson, P., et al., Init. Repts. DSDP, 65: Washington (U.S. Govt. Printing Office).

2 Present address: Instituto de Ciencias del Mar y Limnología, Estación Mazatlán, Universidad Nacionál Autónoma de Mexico, Apartado Postal 811, Mazatlán, Sinaloa, Mexico.
}

the samples were not dried prior to the testing. As suggested by Richards (1962), the limits were determined for the entire size fraction rather than for only that portion finer than $0.42 \mu \mathrm{m}(1.25 \phi)$. The Atterberg limits of certain sediments are very sensitive to changes in the interstitial water salt concentration. Although the salt content was not measured in the samples studied here, numerous measurements were made on board ship and are reported elsewhere (Gieskes et al., this volume).

The water content was determined by weighing a representative portion of the sample, drying it overnight in an oven at $110^{\circ} \mathrm{C}$, cooling it in a desiccator, and then reweighing it. Corrections have not been made for salt content; thus the water content values are slightly low (Richards, 1962).

The plasticity index, $P I$, affords a quantitative measurement of the plastic characteristics of a completely remolded sediment sample by defining the range of water content over which the sediment is plastic. The plasticity index is computed from the relation,

$$
P I=L L-P L .
$$

A system of classification developed by Casagrande (1948) uses a plasticity chart relating the plasticity index to the liquid limit (Fig. 2). In this chart, Line A represents an empirical boundary between highly plastic inorganic clays above the line and sediments of low to high plasticity below the line, including inorganic silts and organic silts, clays, and silty clays (Casagrande, 1948; Richards, 1962).

The liquidity index, $B$, relates the natural water content, $w$, to the liquid and plastic limits and is defined as,

$$
B=\frac{w-P L}{P I} .
$$

The activity, $a_{c}$, of a sediment is the ratio of the plasticity index to the clay fraction finer than $2 \mu \mathrm{m}(9 \phi)$,

$$
a_{c}=\frac{P I}{\% \text { by weight finer than } 2 \mu \mathrm{m}}
$$

The following limits have been suggested for seafloor sediments: inactive clay, less than 0.25 ; slightly active, $0.25-0.75$; normal, $0.75-1.25$; active, 1.25-1.75; and very active, greater than 1.75. Other relationships derived from Atterberg limit studies are the flow index, $F_{w}$, which is defined as the slope of the flow curve formed by plotting 


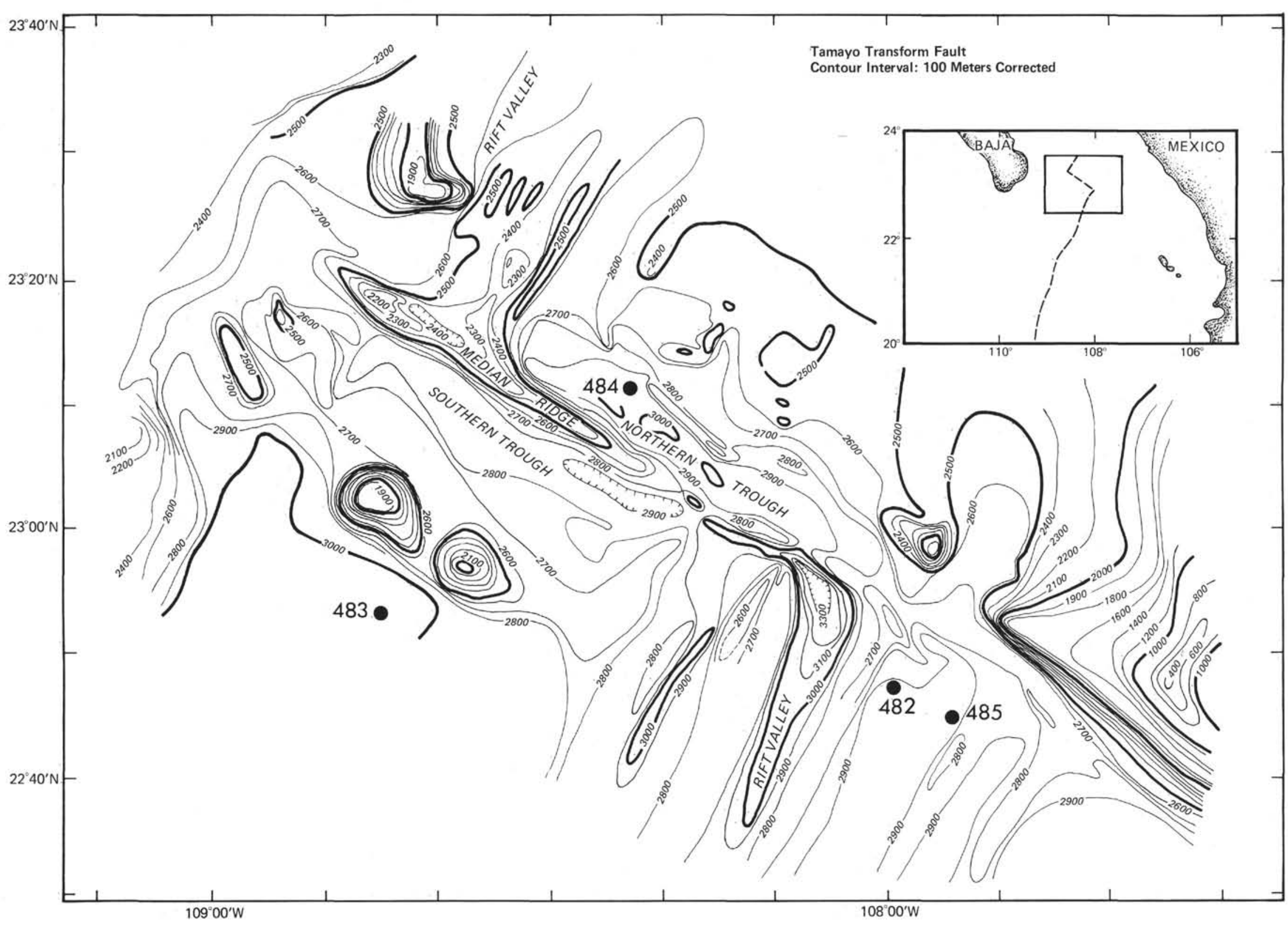

Figure 1. Locations of sites drilled on Leg 65 (contours shown in $\mathrm{m}$ ). 


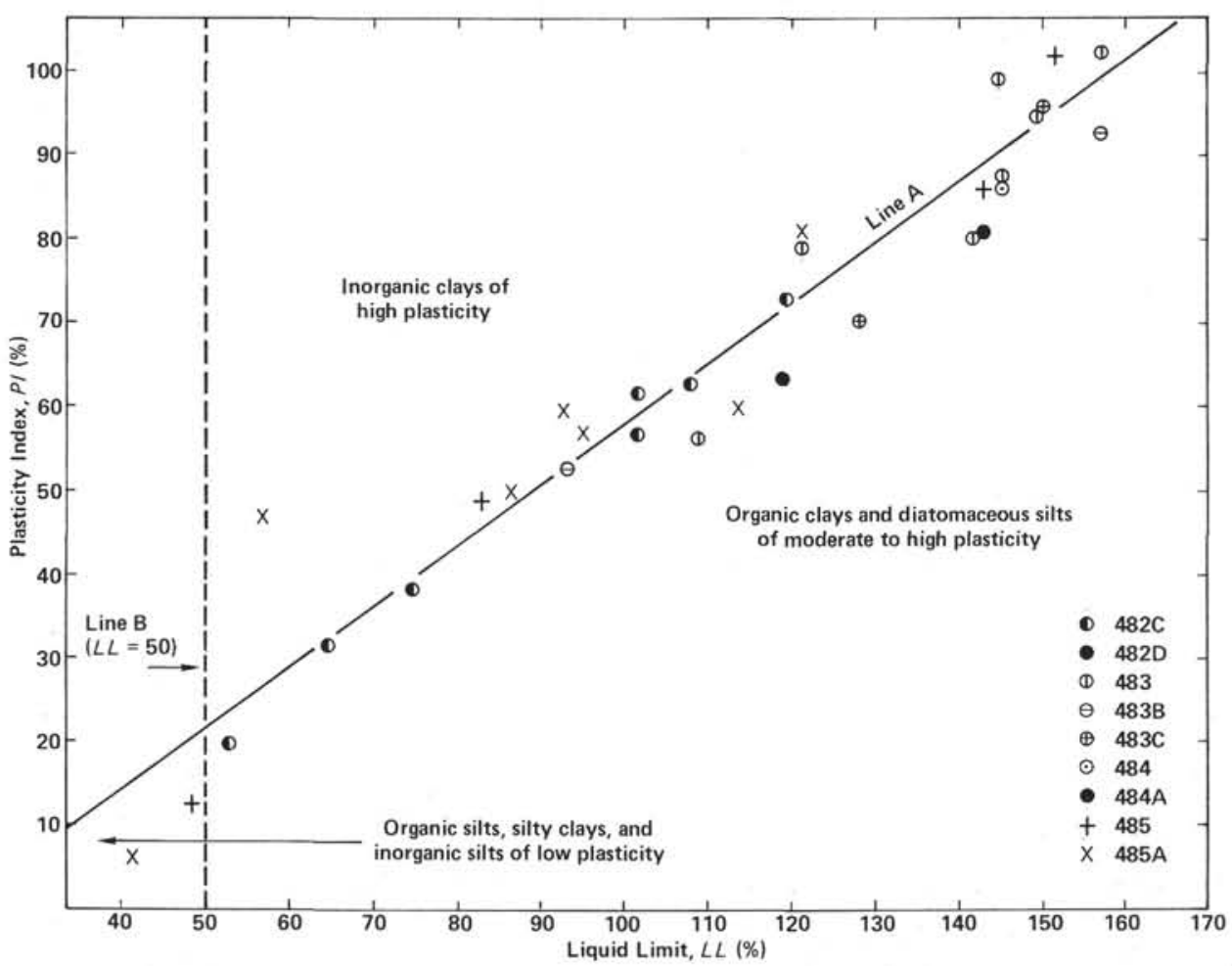

Figure 2. Plasticity index vs. liquid limit for sediments recovered from Sites $484,483,484$, and 485 .

water vs, the number of blows on a log scale, and the toughness index, $T_{w}$, which is defined from the equation,

$$
T_{w}=\frac{P I}{F_{w}} .
$$

\section{RESULTS}

\section{Site $\mathbf{4 8 2}$}

Measured values of the liquid limit at Site 482 (Table 1) range from $52.5 \%$ (Section $482 \mathrm{C}-2-2$ ) to $119.5 \%$ dry weight (Section 482C-7-4). As can be seen in Figure 3, the liquid limit shows a weak tendency to increase with depth. At the same time, the plastic limit values range from $32.8 \%$ (Section $482 \mathrm{C}-2-2$ ) to $46.9 \%$ dry weight (Section 482C-7-4). The plasticity index therefore varies between $19.7 \%$ and $72.6 \%$ for the same samples. The water content decreases irregularly with depth in the section and ranges from $80.8 \%$ at a depth of 69 meters in Hole $482 \mathrm{C}$ to $45.9 \%$ at a depth of 117 meters (Section 482C-3-4). Inorganic clays with liquid limits greater than $50 \%$ are highly plastic. Several of the samples tested from Site 482 are in this category, and two are situated above Line A, the empirical boundary separating organic and inorganic clays (Fig. 2). Most of the samples, however, fall below Line A and would thus be considered organic clays or silts of moderate to high plasticity.

The values of the flow and toughness indices obtained for the sediments at this site vary irregularly with depth, the flow index ranging from approximately $11.5 \%$ (Core $482 \mathrm{C}-2$ ) to about $42.5 \%$ (Core $482 \mathrm{C}-3$ ), while the toughness index ranges from 1.3 to 2.0 (Fig. 3, Table 1).

The liquidity index, on the other hand, was high in the upper part of the column, ranging from $108 \%$ to $214 \%$ (Cores $483 \mathrm{C}-1$ and 2), but diminished with depth to values as low as $31 \%$. Thus the upper 60 meters of the section behaves like a liquid while the remainder behaves like a plastic.

Values of the ratio of the plasticity index to the clay fraction greater than $9.0 \phi$ (i.e., the activity) were high. The samples analyzed range from slightly active $(0.7$ in Core $482 \mathrm{C}-6)$ to very active (3.6 in Core $482 \mathrm{C}-1)$.

\section{Site 483}

Ten samples consisting of soft to very soft diatomaceous silty clay, silt, and clayey silt were analyzed from Holes 483, 483B, and 483C. The clay fraction ranges from approximately $63.0 \%$ at the top of the section to about $20 \%$ at the base, and the average grain size ranges from about $9.0 \phi$ to about $6.6 \phi$ over the same interval (Table 2).

As can be seen in Table 1, the Atterberg limits at Site 483 tend to be higher than those at Site 482 . The average value of the plastic limit, for example, is $55 \%$, while the liquid limit averages $140.0 \%$; the plasticity index averages $86.0 \%$, with occasional values as high as $102.0 \%$ (Core 483-10) and the water content averages $138 \%$, with values as high as $258.8 \%$ (Core $483-6$ ) and as low as $72.7 \%$ (Core $483 \mathrm{C}-3$ ). Similarly the flow index averages $35.0 \%$, with extreme values of $59.0 \%$ and $10.5 \%$ (Cores 483-8 and 10); the toughness index ranges from 
Table 1. Atterberg limits of sediments from Sites $482,483,484$, and 485.

\begin{tabular}{|c|c|c|c|c|c|c|c|c|c|}
\hline $\begin{array}{c}\text { Sample } \\
\text { (interval in cm) }\end{array}$ & $\begin{array}{l}\text { Depth } \\
(\mathrm{m})\end{array}$ & $\begin{array}{c}\text { Plastic } \\
\text { Limit, } P L \\
(\%)\end{array}$ & $\begin{array}{c}\text { Liquid } \\
\underset{\text { Limit, } L L}{(\%)}\end{array}$ & $\begin{array}{c}\text { Plasticity } \\
\text { Index, PI } \\
(\%)\end{array}$ & $\begin{array}{c}\text { Water } \\
\text { Content, w } \\
(\%)\end{array}$ & $\begin{array}{c}\text { Flow } \\
\text { Index, } F_{w} \\
(\%)\end{array}$ & $\begin{array}{l}\text { Toughness } \\
\text { Index, } T_{w}\end{array}$ & $\begin{array}{c}\text { Liquidity } \\
\text { Index, } B \\
(\%)\end{array}$ & Activity, $a_{C}$ \\
\hline \multicolumn{10}{|l|}{ Hole $482 \mathrm{C}$} \\
\hline $1-2,15-30$ & 46.15 & 36.5 & 74.6 & 38.1 & 77.8 & 24.0 & 1.6 & 108.4 & 3.6 \\
\hline $2-2,135-150$ & 56.85 & 32.8 & 52.5 & 19.7 & - & 11.5 & 1.7 & 214.2 & 2.3 \\
\hline $3-4,135-150$ & 69.35 & 45.0 & 107.5 & 62.5 & 80.8 & 42.5 & 1.5 & 57.3 & 1.6 \\
\hline $4-4,135-150$ & 78.85 & 40.4 & 101.5 & 61.1 & 77.8 & 30.2 & 2.0 & 61.2 & 3.5 \\
\hline $5-5,135-150$ & 89.85 & 44.7 & 101.5 & 56.8 & 70.9 & 40.0 & 1.4 & 46.1 & 1.3 \\
\hline $6-4,135-150$ & 116.85 & 32.9 & 64.5 & 31.6 & 45.9 & 24.7 & 1.3 & 41.1 & 0.7 \\
\hline $7-4,135-150$ & 126.35 & 46,9 & 119.5 & 72.6 & 69.6 & 37.0 & 2.0 & 31.3 & 2.3 \\
\hline \multicolumn{10}{|l|}{ Hole 482D } \\
\hline $3-6,135-150$ & 98.85 & 41.0 & 93.5 & 52.5 & 54.4 & 38.0 & 1.4 & 25.5 & 1.5 \\
\hline \multicolumn{10}{|l|}{ Hole 483} \\
\hline $2-2,105-120$ & 3.15 & 61.0 & 141.2 & 80.2 & 182.3 & 41.0 & 2.0 & 151.3 & 1.3 \\
\hline $4-2,129-144$ & 22.79 & 57.2 & 144.6 & 87.4 & 136.1 & 33.5 & 2.6 & 90.3 & 1.4 \\
\hline $6-2,135-150$ & 41.85 & 50.0 & 149.0 & 99.0 & 258.8 & 27.5 & 3.6 & 210.9 & 1.7 \\
\hline $8-3,105-120$ & 62.05 & 51.6 & 108.5 & 56.9 & 75.1 & 59.0 & 1.0 & 41.3 & 1.6 \\
\hline $9-4,135-150$ & 73.35 & 54.5 & 149.0 & 94.5 & 127.4 & 28.5 & 3.3 & 77.1 & 4.1 \\
\hline $10-1,135-150$ & 78.35 & 55.5 & 157.5 & 102.0 & 181.6 & 10.5 & 9.7 & 123.6 & 5.2 \\
\hline $11-2,135-150$ & 89.35 & 42.2 & 121.2 & 78.8 & 101.9 & 31.8 & 2.5 & 75.8 & 2.8 \\
\hline \multicolumn{10}{|l|}{ Hole 483B } \\
\hline $1-4,129-144$ & 97.29 & 65.1 & 157.0 & 92.4 & 93.1 & 56.5 & 1.6 & 30.3 & 1.7 \\
\hline \multicolumn{10}{|l|}{ Hole $483 \mathrm{C}$} \\
\hline $1-4,135-150$ & 44.35 & 54.3 & 150.0 & 95.7 & 151.2 & 35.0 & 2.7 & 101.3 & 5.4 \\
\hline $3-2,0-15$ & 97.00 & 57.7 & 128.2 & 70.5 & 72.7 & 27.5 & 2.6 & 21.3 & 1.5 \\
\hline \multicolumn{10}{|l|}{ Hole 484} \\
\hline $1-1,135-150$ & 1.35 & 58.0 & 144.5 & 86.5 & 151.5 & 37.0 & 2.3 & 108.1 & 1.4 \\
\hline \multicolumn{10}{|l|}{ Hole 484A } \\
\hline $2-3,135-150$ & 12.35 & 55.3 & 118.5 & 63.3 & 92.8 & 95.0 & 0.7 & 59.2 & 1.7 \\
\hline $4-3,135-150$ & 31.35 & 62.1 & 142.8 & 80.7 & 115.2 & 34.0 & 2.4 & 65.8 & - \\
\hline \multicolumn{10}{|l|}{ Hole 485} \\
\hline $1-1,129-144$ & 1.29 & 52.5 & 151.5 & 99.0 & 163.9 & 47.0 & 2.1 & 112.5 & 1.9 \\
\hline $3-5,135-150$ & 19.85 & 57.2 & 143.0 & 85.8 & 122.4 & 36.0 & 2.4 & 76.0 & 1.4 \\
\hline $4-1,135-150$ & 23.35 & 35.2 & 47.8 & 12.6 & 50.9 & 15.0 & 0.8 & 124.6 & 0.6 \\
\hline $5-2,135-150$ & 34.35 & 34.0 & 82.5 & 48.5 & 74.8 & 21.5 & 2.3 & 84.1 & 1.1 \\
\hline \multicolumn{10}{|l|}{ Hole 485A } \\
\hline $1-5,129-144$ & 57.79 & 40.3 & 121.0 & 80.7 & 65.9 & 45.0 & 1.8 & 31.7 & 1.6 \\
\hline $3-2,129-144$ & 72.29 & 43.5 & 103.5 & 60.0 & 69.3 & 45.0 & 1.3 & 43.0 & 1.5 \\
\hline $5-3,129-144$ & 92.92 & 38.6 & 56.5 & 46.9 & 39.6 & 17.0 & 2.8 & 2.1 & 1.4 \\
\hline $8-2,135-150$ & 119.85 & 36.7 & 86.3 & 49.6 & - & 40.5 & 1.2 & - & 1.3 \\
\hline $9-2,135-150$ & 129.35 & 35.6 & 41.5 & 5.9 & 42.3 & 13.0 & 0.5 & 113.6 & 0.7 \\
\hline $20-1,135-150$ & 193.35 & 33.6 & 93.0 & 59.4 & 41.7 & 34.0 & 1.8 & 13.6 & 13.6 \\
\hline $22-4,135-150$ & 207.35 & 38.2 & 95.0 & 56.8 & 42.0 & 58.0 & 1.0 & 6.7 & 3.8 \\
\hline
\end{tabular}

9.7 (Hole 483, Core 10) to 1.0 (Core 483-8) and averages 3.0 , and the liquidity index varies between $210.9 \%$ (Core $483-6$ ) and $21.3 \%$ (Core $483 \mathrm{C}-3$ ) with an average of $173.0 \%$. Finally, the activity ranges from 1.3 to 5.4 , which indicates that most of the samples are very active.

All of the samples from Site 483 have liquid limits greater than $50 \%$ and most of them are inorganic and highly plastic (Fig. 2). Several samples from the holes investigated, however, fall below Line $\mathrm{A}$ and would thus be considered highly plastic organic clays.

\section{Site 484}

The samples examined from Site 484 consist of hemipelagic clayey silts and silty clays with an average clay content of about $50 \%$. The average grain size ranges between 7.0 and $9.0 \phi$. The average values of the limits are: plastic limit, $60.0 \%$; liquid limit, $135.0 \%$; plasticity index, $76.0 \%$; water content, $120.0 \%$; flow index, $55.0 \%$; toughness index, 1.8 ; liquidity index, $78.0 \%$; and activity, 1.6 (active). On this basis, the sediments analyzed would be considered organic clays of high plasticity. Since only three samples from Site 484 were analyzed, however, the values obtained cannot be considered representative.

\section{Site 485}

The sedimentary sequence above the basement at Site 485 is variable and ranges from hemipelagic, very poorly sorted clayey silts to silty clays with minor terrigenous sandy silts. The sediments interlayered with the basalts are silts and clayey silts. Eleven samples were analyzed from this site, nine from the sequence overlying the ba- 


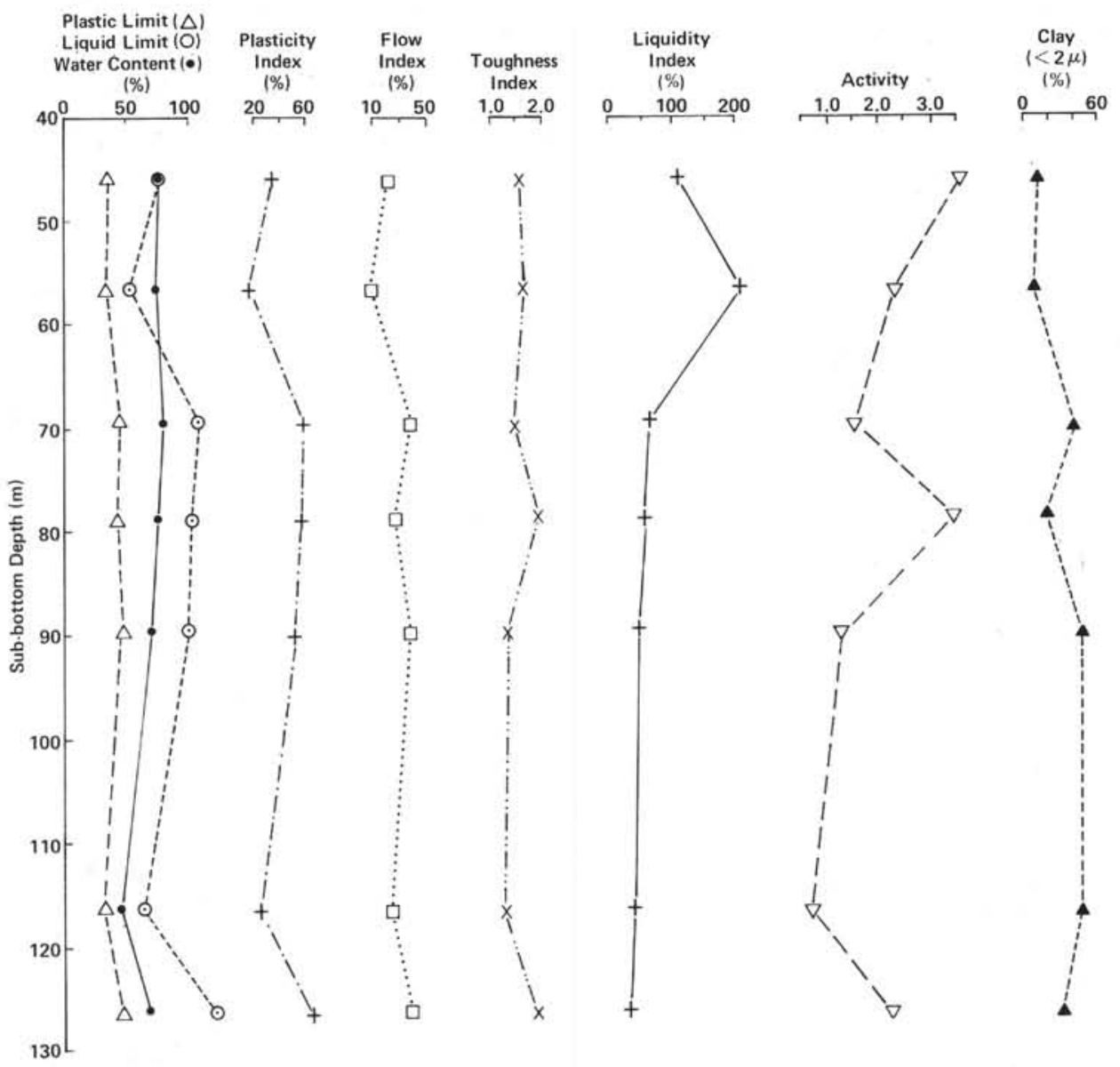

Figure 3. Atterberg limits vs. depth, Hole 482C.

salts (Hole 485, Cores 1, 3, 4, and 5; Hole 485A, Cores 1, $3,5,8$, and 9), and two from the interlayered sediments (Hole 485A, Cores 20 and 22).

\section{Hole 485}

The sediments from Hole 485 consist entirely of silty clays (with an average clay content of $55.0 \%$ ) and clayey silts ( $32.0 \%$ clay). The samples from Cores 1 and 4 are terrigenous with about $2.0 \%$ and $17.0 \%$ sand, respectively (Gutierréz-Estrada, this volume). The average values of the plastic and liquid limits are $44.0 \%$ and $106.0 \%$, respectively, while the plasticity index and the water content average $61.0 \%$ and $103.0 \%$. Similarly, the flow index averages $30.0 \%$, the toughness index, 1.9 , the liquidity index, $99 \%$, and the activity, 1.3 (active to very active). As can be seen in Figure 3, the sediments in Hole 485 range from inorganic clays of high plasticity (Core 1) to inorganic silts of low plasticity (Core 4).

\section{Hole 485A}

The sediments recovered above the basement in Hole $485 \mathrm{~A}$ range from very poorly sorted, nearly symmetrical, silty clay $(50.0 \%$ clay $)$ to poorly sorted, fineskewed, clayey silts ( $37.0 \%$ clay), and poorly sorted, fine-skewed, terrigenous sandy silts $(16.0 \%$ sand, $9.0 \%$ clay). The sediments interlayered in the basement are poorly sorted silts ( $7.0 \%$ clay) in which the sorting ranges downward from fine- to coarse-skewed (Gutiérrez-Estrada, this volume).

As can be seen in Table 1, the plastic and liquid limits average $39.0 \%$ and $82.0 \%$, respectively, in those sediments above the basement, with the values for both tending to decrease with depth. Similarly, the plasticity index averages $49.0 \%$; the water content, $54.0 \%$; the flow index, $32.0 \%$; the toughness index, 1.5 ; the liquidity index, $47.0 \%$; and the activity, 1.3 (active). Significant departures from these general values are observed, however, in the sediments interpreted as terrigenous (e.g., Core 9) for which the plasticity index, flow index, toughness index, and activity are as low as $5.9 \%$, $13.0 \%, 0.5$, and 0.7 (slightly active), respectively, and the liquidity index is as high as $113.6 \%$. This sediment displays moderate plasticity and a liquid limit of $41.5 \%$.

The sediments interlayered in the basement, on the other hand, display the following average limits and indices: plastic limit, $36.0 \%$; liquid limit, $94.0 \%$; plasticity index, $58.0 \%$; water content, $42.0 \%$; flow index, $46.0 \%$; toughness index, 1.5 ; liquidity index, $10.0 \%$; and activity, 8.7 (very active).

\section{DISCUSSION}

The plastic and liquid limits of the sediments examined in this study range widely from $32.8 \%$ to $65.1 \%$, 
Table 2. Grain size parameters of sediments from Sites 482, 483, 484, and 485 .

\begin{tabular}{|c|c|c|c|c|c|}
\hline \multirow[b]{2}{*}{$\begin{array}{l}\text { Sample } \\
\text { (interval in } \mathrm{cm} \text { ) }\end{array}$} & \multicolumn{4}{|c|}{ Statistical Parameters } & \multirow[b]{2}{*}{ Lithology } \\
\hline & $\begin{array}{l}\text { Depth } \\
\text { (m) }\end{array}$ & $5 \phi^{\mathrm{a}}$ & $\begin{array}{c}\text { Average } \\
\text { Grain } \\
\text { Size }(\phi)\end{array}$ & $\begin{array}{c}\text { Clay Size } \\
\text { Fractionb } \\
(\%)\end{array}$ & \\
\hline
\end{tabular}

Hole $482 \mathrm{C}$

\begin{tabular}{|c|c|c|c|c|c|}
\hline $1-2,15-30$ & 46.15 & 4.62 & 6.76 & 10.7 & Silt \\
\hline $2-2,135-150$ & 56.85 & 3.96 & 6.17 & 8.6 & Silt \\
\hline $3-4,135-150$ & 69.35 & 4.41 & 7.76 & 38.9 & Clayey silt \\
\hline $4-4,135-150$ & 78.85 & 2.10 & 5.26 & 17.6 & Sandy silt \\
\hline $5-5,135-150$ & 89.85 & 4.25 & 7.27 & 44.4 & Clayéy silt \\
\hline $6-4,135-150$ & 116.85 & 5.09 & 8.28 & 44.3 & Clayey silt \\
\hline $7-4,135-150$ & 126.35 & 2.35 & 7.12 & 31.7 & Clayey silt \\
\hline \multicolumn{6}{|l|}{ Hole 482D } \\
\hline $3-6,135-150$ & 98.85 & 4.94 & 6.99 & 34.7 & Clayey silt \\
\hline \multicolumn{6}{|l|}{ Hole 483} \\
\hline $2-2,105-120$ & 3.15 & 5.40 & 9.00 & 63.5 & Silty clay \\
\hline $4-2,129-144$ & 22.79 & 5.35 & 8.86 & 63.8 & Silty clay \\
\hline $6-2,135-150$ & 41.85 & 4.55 & 8.72 & 59.4 & Silty clay \\
\hline $8-3,105-120$ & 62.05 & 4.30 & 7.25 & 34.9 & Clayey silt \\
\hline $9-4,135-150$ & 73.35 & 4.52 & 6.60 & 22.9 & Silt \\
\hline $10-1,135-150$ & 78.35 & 4.46 & 6.62 & 19.8 & Silt \\
\hline $11-2,135-150$ & 89.35 & 4.78 & 7.06 & 28.1 & Clayey silt \\
\hline \multicolumn{6}{|l|}{ Hole 483B } \\
\hline $1-4,129-144$ & 97.29 & 5.35 & 8.42 & 53.5 & Silty clay \\
\hline \multicolumn{6}{|l|}{ Hole 483C } \\
\hline $1-4,135-150$ & 44.35 & 5.06 & 6.85 & 17.6 & Silt \\
\hline $3-2,0-15$ & 97.00 & 4.80 & 7.79 & 48.5 & Clayey silt \\
\hline \multicolumn{6}{|l|}{ Hole 484} \\
\hline $1-1,135-150$ & 1.35 & 5.12 & 8.78 & 60.9 & Silty clay \\
\hline \multicolumn{6}{|l|}{ Hole 484A } \\
\hline $2-3,135-150$ & 12.35 & 4.21 & 7.30 & 36.4 & Clayey silt \\
\hline $4-3,135-150$ & 31.35 & - & - & - & Muddy siliceous ooze \\
\hline \multicolumn{6}{|l|}{ Hole 485} \\
\hline $1-1,129-144$ & 1.29 & 5.62 & 8.78 & 51.6 & Silty clay \\
\hline $3-5,135-150$ & 19.85 & 5.61 & 8.00 & 60.4 & Silty clay \\
\hline $4-1,135-150$ & 23.35 & 3.29 & 5.73 & 20.2 & Clayey silt \\
\hline $5-2,135-150$ & 34.35 & 4.71 & 8.01 & 45.6 & Clayey silt \\
\hline \multicolumn{6}{|l|}{ Hole 485A } \\
\hline $1-5,129-144$ & 57.79 & 4.68 & 7.95 & 50.6 & Silty clay \\
\hline $3-2,129-144$ & 72.29 & 4.79 & 7.22 & 41.0 & Clayey silt \\
\hline $5-3,129-144$ & 92.92 & 4.65 & 7.12 & 33.7 & Clayey silt \\
\hline $8-2,135-150$ & 119.85 & 4.80 & 7.58 & 37.7 & Clayey silt \\
\hline $9-2,135-150$ & 129.35 & 3.64 & 4.88 & 9.0 & Sandy silt \\
\hline $20-1,135-150$ & 193.35 & 4.49 & 6.09 & 4.4 & Silt \\
\hline $22-4,135-150$ & 207.35 & 4.94 & 6.95 & 14.8 & Silt \\
\hline
\end{tabular}

a The coarsest $5 \%$ of the distribution.

${ }^{\mathrm{b}}$ Less than $2 \mu \mathrm{m}$.

and 41.5 and 157.5 , respectively, with most samples ranging from $35 \%$ to $60 \%$ for the plastic limit and $90 \%$ to $140 \%$ for the liquid limit. The plasticity index, which defines the range of water content over which the sediment is plastic (Richards, 1962), ranges from 5.9\% to $102.0 \%$, with most values ranging from $40 \%$ to $100 \%$.

The water content ranged from $41.7 \%$ to $258.8 \%$. In general, the water content varied inversely with depth, but some irregularities attributed to the presence of turbidites rich in sand and skeletal remains were observed. The natural water content exceeded the plastic limit in all of the samples and was greater than the liquid limit in nine, of which seven were from sub-bottom depths of less than 60 meters. Thus, from an engineering standpoint, most of the sediments studied deform plastically, but those from the uppermost 50 to 60 meters often behave like a liquid. This observation is consistent with the drilling experience on Leg 65 in that the uppermost sediments at all of the sites could easily be washed to a depth of about 50 meters.

The liquidity index, which is a measure of the degree to which a sample approaches the liquid limit, ranged from $2.1 \%$ to $214.2 \%$ in the samples studied. This index is generally close to $100 \%$ (i.e., the water content equals the liquid limit) in most surficial sediments and exceeds $200 \%$ in sediments formed by settling from a clay suspension (Richards, 1962). As expected, the liquidity index was equal to or greater than $100 \%$ in all of the surficial sediments measured and in two instances, at slightly greater depths, exceeded $200 \%$ (Cores 482C-2 and 483-6 at 56.85 and 41.85 meters, respectively). Although the latter might be attributed to the mode of deposition, the high liquidity index values noted at still greater depths are probably the result of drilling disturbance.

The toughness index and the flow index are useful in the further differentiation of clays. Normally, the toughness index ranges between 1.0 and 3.0 (JuárezBadillo and Rico-Rodriguez, 1975) and most of the samples analyzed in this study range between these limits. Some samples, however, show values as high as 9.7 and as low as 0.5 . The former value is related to a poorly sorted, fine-skewed silt that could be the basal layer of a turbidite sequence. The latter value was determined from a sandy silt containing $13.0 \%$ sand.

If the plasticity index is plotted against the clay-size fraction as in Figure 4, it is clear that most of the samples analyzed are active to very active. Sediments with a low clay content and a low plasticity index, however, fall between the 0.25 and 0.75 lines and are classified as only slightly active.

\section{CONCLUSIONS}

The sediments recovered at the mouth of the Gulf of California on Leg 65 consist almost entirely of silty clays and clayey silts of Pleistocene age. With the exception of several thin units immediately overlying the basement which may have been diagenetically altered, all of the sediments cored at Sites $482,483,484$, and 485 were either unconsolidated or only weakly consolidated. This is clearly reflected in the Atterberg limits of the samples, which indicate that the water content of the sediments commonly exceeds the liquid limit to a sub-bottom depth of at least 60 meters and invariably exceeds the plastic limit at least to the sediment/basement contact. At greater depths, however, it is anticipated that the sediments will be semisolid as a result of decreasing water content. Although the mechanical behavior of such a column under dynamic loading is not well known, it is quite conceivable that significant portions of the column might be subject to liquefaction during the numerous earthquakes that visit the region. If so, at least some of the turbidites found in the section may have been earthquake-induced (Almagor and Wiseman, 1977). 


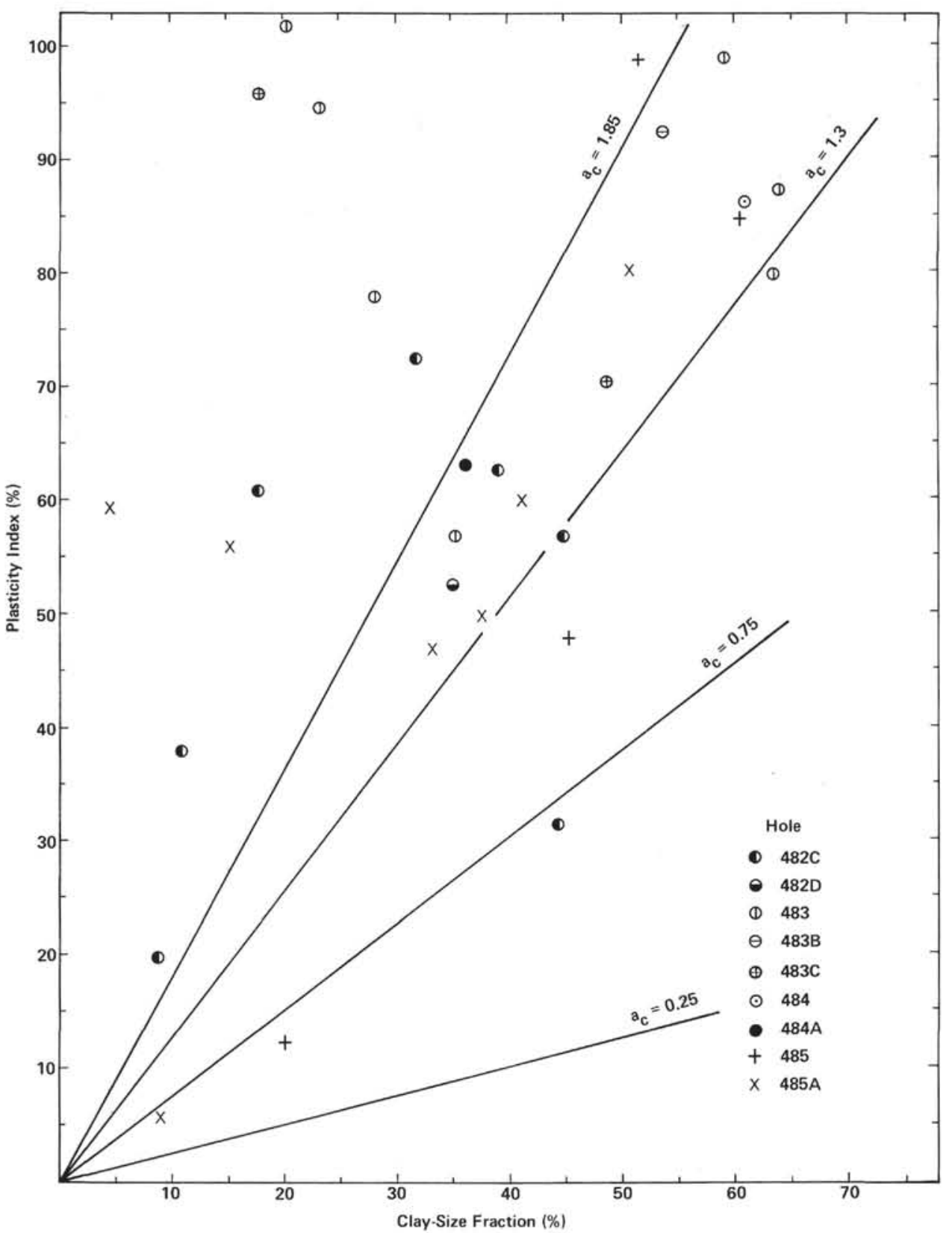

Figure 4. Plasticity index vs. clay-size fraction and activity for sediments recovered from Sites 484, 483, 484 , and 485 .

\section{ACKNOWLEDGMENTS}

The writers wish to express their appreciation to the following individuals from the Universidad Nacionál Autónoma de México for their cooperation in this study: A. Ayala-Castañares, Director del Instituto de Ciencias del Mar y Limnología; A. Laguarda-Figueras, ExDirector del Centro de Ciencias del Mar y Limnología; G. Hiriart, Instituto de Ingeniería; A. Pérez-Rojas, A. Galavíz-Solis, and E. Leon, who typed the manuscript.

\section{REFERENCES}

Almagor, G., and Wiseman, G., 1977. Analysis of submarine slumping in the continental slope off the southern coast of Israel. Mar. Geotech., 2:349-388.

American Society for Testing Materials, 1958. ASTM Standards Including Tentatives (Vol. 4): Philadelphia, (ASTM).
Casagrande, A., 1932. Research on the Atterberg limits of scils. Public Roads, 13:121-136.

1948. Classification and identification of soils. Am. Soc. Civil Engineers Trans., 113:901-931.

Juárez-Badillo, E., and Rico-Rodríguez, A., 1975. Mecanica de Suelos, Tomo 1. Fundamentos de la Mecanica de Suelos: Mexico City (Editorial Limusa).

Keller, G. H., and Bennett, R. H., 1973. Sediment mass physical properties-Panama Basin and northeastern equatorial Pacific. In Van Andel, Tj. H., Heath, G. R., et al., Init. Repts. DSDP, 16: Washington (U.S. Govt. Printing Office), 499-512.

Richards, A. F., 1962. Investigations of Deep-Sea Sediments Cores, II. Mass Physical Properties: Washington (U.S. Navy Hydrographic Office). 